\title{
Rett til helsehjelp for papirløse migranter
}

\author{
Papirløse migranter er mennesker som oppholder seg i Norge ulovlig. De har rett på \\ øyeblikkelig helsehjelp i henhold til lov om spesialisthelsetjenesten og lov om kommune- \\ helsetjenesten, nødvendig helsehjelp etter lov om kommunehelsetjenesten og rett til \\ hjelp etter smittevernloven.
}

\section{Susanna Aschehoug}

v.s.j.aschehoug@student.jus.uio.no

Sognsveien $102 \mathrm{H}$

0856 Oslo

I Norge finnes det rundt 12 000-18 000 papirløse migranter. Blant disse er det personer som har fått avslag på asylsøknad eller som ikke søkt om oppholdstillatelse, personer som er blitt utsatt for menneskehandel eller personer som er på drift i Europa. Mange pasienter i denne gruppen sliter med store helseproblemer. Kirkens Bymisjon og Oslo Røde Kors etablerte høsten 2009 et helsesenter for papirløse migranter der det ytes gratis nødvendig helsehjelp ved frivillig innsats fra helsepersonell. Med denne artikkelen ønsker jeg å belyse de rettighetene denne gruppen har etter norsk lov.

Etter grunnloven $\S 110 \mathrm{c}$ påligger det statens myndigheter å respektere og sikre menneskerettighetene. Som norsk rett gjelder blant annet konvensjonen om menneskerettigheter, økonomiske, sosiale og kulturelle rettigheter og barns rettigheter. Disse er inkorporert som gjeldende i norsk rett (1). En konvensjon er en avtale mellom et stort antall stater. Ved motstrid mellom regler i norsk rett og inkorporert folkerett, vil konvensjonen ha forrang fremfor intern rett jfr. menneskerettsloven $\S 3$.

Etter den europeiske menneskerettskonvensjonen artikkel 2 er retten til liv beskyttet (1). Dette er den mest grunnleggende menneskerettigheten. Retten til liv har fått en fremtredende plassering $\mathrm{i}$ både konvensjonen om sivile og politiske rettigheter (1) og i konvensjonen om økonomiske, sosiale og kulturelle rettigheter (1). En ubehandlet sykdomstilstand som under normale omstendigheter kan behandles, og som fører til tap av liv på grunn av manglende helsetilbud, vil krenke retten til liv.

Retten til helse er beskyttet i artikkel 12 i konvensjonen om økonomiske, sosiale og kulturelle rettigheter: «Alle skal nyte den høyest oppnåelige helsestandard.» Dette kan kanskje fremstå som en noe pompøs formulering, men den må tolkes i sammenheng med artikkel 2, første ledd i samme konvensjon. Denne slår fast at rettighetene skal realiseres over tid og avhengig av statenes økonomiske situasjon. FNs komité for økonomiske, sosiale og kulturelle rettigheter har beskrevet et minimumsnivå i sin generelle kommentar om helse, der blant annet statene skal sikre retten til tilgang på helsetilbud. Denne rettigheten, som gjelder alle og enhver - også den som oppholder seg ulovlig i landet, er vernet etter denne bestemmelsen. Norge er på denne måten forpliktet til å yte helsehjelp til de papirløse migrantene.

Etter barnekonvensjonen har barn en utvidet rett til helsehjelp (1). Etter artikkel 24 skal barn sikres nødvendig helsehjelp og et behandlingstilbud for sykdom og rehabilitering. Denne utvidede retten til helsehjelp kommer også frem av kommunehelsetjenesteloven $\S 2$ 2-2.

Lovgiver har ønsket å gjøre det klart at humanitær bistand bestående av legehjelp ikke er ulovlig. Dette har kommet til uttrykk i et nytt 5 . ledd i utlendingsloven $\S 108$ (2). Denne loven trådte i kraft 1.1. 2010. Der kommer det klart frem at den som yter humanitær bistand til en utlending som oppholder seg ulovlig i riket, ikke skal kunne straffes for medvirkning til ulovlig opphold.

\section{Helsehjelp etter pasientrettighetsloven}

Pasientrettighetsloven gjelder for alle som oppholder seg i riket, også dem som er på ferie, jobb, gjennomreise eller er i landet ulovlig (3). Dette fremgår av loven § 1-2. Det er åpnet for unntak fra lovens kapittel 2 i forskrift, og dette er gjort i prioriteringsforskriften $\S 1$ (4). Etter denne forskriften gjelder $\S 2-1$ første ledd i pasientrettighetsloven alle og enhver, mens de øvrige leddene i samme paragraf, som blant annet gjelder nødvendig helsehjelp i spesialisthelsetjenesten, kun gjelder personer som enten har fast bopel eller oppholdssted i riket, er medlemmer av folketrygden, eller der staten har inngått en gjensidighetsavtale med en annen stat (konvensjonspasient).

\section{$\emptyset y e b l i k k e l i g$ hjelp etter lov om spesialisthelsetjenesten}

Øyeblikkelig hjelp etter spesialisthelsetjenesten er regulert i § 3-1 (5). Sykehus og fødestuer har etter denne reglen en plikt til straks å motta en pasient som trenger øyeblikklig helsehjelp dersom det er «påtrengende nødvendig», dvs. et vilkår som må være oppfylt for at helsehjelpen skal ytes. Dette følger også av helsepersonelloven $\S 7$, som pålegger helsepersonell å yte helsehjelpen når det må antas at helsehjelpen er «påtrengende nødvendig» (6). Vilkåret er meget strengt: det kan være spørsmål om å redde liv, avverge alvorlig helseskade, hindre vesentlig forverring av helsetilstanden, gjenopprette vitale funksjoner eller hindre sterke smertetilstander (7).

\section{Helsehjelp etter lov om kommunehelsetjenesten}

Etter $\S 2-1$ første ledd i kommunehelsetjenesteloven har enhver «(...) rett til nødvendig helsehjelp i den kommunen der han eller hun bor eller midlertidig oppholder seg (...)» (8). I begrepet «nødvendig helsehjelp» ligger det et strengt krav. Det må legges avgjørende vekt på den hjelptrengendes behov etter en helsefaglig vurdering. Det må også være adgang til å legge en viss vekt på hvor nyttig det er for pasienten å få helsehjelp. Av samme lov § 2-2 fremgår det at barn har utvidet rett til helsekontroll i den kommunen barnet bor eller midlertidig oppholder seg. Dette gjelder alle barn. Her har lovgiver definert helsekontroll til å være nødvendig helsehjelp.

Ut fra dette har papirløse migranter rett på øyeblikkelig hjelp fra spesialisthelsetjenesten og kommunehelsetjenesten og nødvendig helsehjelp fra kommunehelsetjenesten.

\section{Helsehjelp etter smittevernloven}

Rett til smittevernhjelp er regulert i smittevernloven kapittel 6 (9). Enhver har rett til 
nødvendig smittevernhjelp. Smittevernhjelp anses som en del av rett til nødvendig helsehjelp fra kommunehelsetjenesten og spesialisthelsetjenesten, jf. § 6-1. Denne retten gjelder for alle personer, også dem med ulovlig opphold og som er i fare for å bli smittet med en allmennfarlig smittsom sykdom. De har rett til helsehjelp i form av vaksinasjon, informasjon og annen nødvendig forebyggende hjelp. De som er smittet med en allmennfarlig smittsom sykdom, har rett til medisinsk vurdering og utredning, behandling, pleie og annen nødvendig smittevernhjelp.

Denne helsehjelpen og tiltak som iverksettes som nevnt over, er gratis for den som er i fare for å bli smittet eller er smittet, jf. $\S 6-2$. Hvilke sykdomstilstander som er definert som allmennfarlige smittsomme sykdommer, er regulert i forskrift (10).

\section{Ingen refusjon}

I folketrygdloven $\S 5-2$ sammenholdt med $\S 2-1$ tredje ledd er vilkår for rett til stønad ved helsetjenester at vedkommende er medlem av folketrygden, har lovlig opphold i riket eller er en såkalt konvensjonspasient (11). Dette vilkåret skal forhindre at personer som kommer til Norge og oppholder seg ulovlig i landet, får rett til gratis ytelser her. Lege eller helseforetak som plikter å behandle pasienter i denne gruppen, vil derfor ikke ha rett til refusjonstakster fra helseøkonomiforvaltningen (Helfo). Dette kommer også til uttrykk i spesialisthelsetjenesten $\S 5-3$. Unntatt fra denne bestemmelsen er retten til helsehjelp etter smittevernloven. Den øvrige helsehjelpens kostnader må gå på legens/helseforetakets pro bono/godhet, da disse pasientene som oftest ikke har økonomi til å betale for seg.

Oppgitte interessekonflikter: Ingen

Litteratur
1. LOV-1999-05-21-30. Lov om styrking av menneskerettighetenes stilling i norsk rett Imenneskeretts(oven).
2. LOV-2008-05-15-35. Lov om utlendingers adgang til riket og deres opphold her (utlendingsloven).

3. LOV-1999-07-02-63. Lov om pasientrettigheter (pasientrettighetsloven).

4. FOR-2000-12-01-1208. Forskrift om prioritering av helsetjenester, rett til nødvendig helsehjelp fra spesialisthelsetjenesten, rett til behandling i utlandet og om klagenemnd (prioriteringsforskriften).

5. LOV-1999-07-02-61. Lov om spesialisthelsetjenesten m.m. (spesialisthelsetjenesteloven).

6. LOV-1999-07-02-64. Lov om helsepersonell m.v. (helsepersonelloven).

7. Befring AK, Ohnstad B. Helsepersonelloven med kommentarer. Bergen: Fagbokforlaget, 2001.

8. LOV-1982-11-19-66. Lov om helsetjenesten i kommunene (kommunehelsetjenesteloven).

9. LOV-1994-08-05-55. Lov om vern mot smittsomme sykdommer (smittevernloven).

10. FOR-1995-01-01-100. Forskrift om allmennfarlige smittsomme sykdommer.

11. LOV-1997-02-28-19. Lov om folketrygd (folketrygdloven).

Manuskriptet ble mottatt 13.10. 2009 og godkjent 11.2. 2010. Medisinsk redaktør Petter Gjersvik. 